\title{
A POLÊMICA DA DIREITA BRASILEIRA SOBRE IMIGRANTES: UM ESTUDO COGNITIVO-RETÓRICO
}

\begin{abstract}
Douglas Rabelo de Sousa (USP)
Analisaremos dois textos online que compõem uma polêmica da direita brasileira, iniciada em setembro de 2015 por Jair Bolsonaro ao chamar os imigrantes de "escória do mundo" em uma entrevista para o Jornal Opção de Goiânia.O primeiro refere-se ao artigo de opinião de Leandro Narloch "Deixe a escória entrar, Bolsonaro, pois faremos com ela um grande país," publicado em 23 de setembro de 2015, no blog da Veja, e o segundo diz respeito a um vídeo publicado no Youtube em 16 de novembro de 2015, de Olavo de Carvalho, intitulado "Leandro Narloch e o Politicamente Correto". Em ambos os textos os autores abordam suas visões sobre imigrantes de países como Haiti, Senegal, Síria, Irã e Bolívia e como o Brasil deve agir em relação a estes imigrantes. Narloch, com uma visão liberal, preconiza a liberdade de circulação de imigrantes por servirem de mão de obra internacional barata e por serem comparáveis aos imigrantes italianos, japoneses, poloneses e alemães que chegaram ao Brasil no fim do século XIX enquanto Carvalho se mostra relutante e contrário a estes imigrantes contemporâneos ao passo que não aceita a comparação do grupo atual com os imigrantes do fim do século XIX,devido, segundo Carvalho, "ao progresso" e à proposta civilizatória trazidos pelos grupos mencionados anteriormente. Nosso objetivo com este trabalho é analisar a função das analogias e desanalogias apresentadas pelos dois autores para depreender como esses processos cognitivos servem de base para seus argumentos e ideologias. Como fundamentação teórica usaremos Gentner (1999); Smith (2012) para abordar analogia e desanalogia; Van Dijk (2014) e Gonçalves-Segundo (2016) para depreender as ideologias e Toulmin (1958) para tratarmos da estrutura funcional da argumentação.
\end{abstract}

Palavras-chave: Imigração, Analogia e Desanalogia, Direita Brasileira 